\title{
DIGLOSIA
}

Volume 3, Nomor 1, Februari 2020, Halaman 24-32

p-ISSN 2615-725X (Print) e-ISSN 2615-8655 (Online)

http://diglosiaunmul.com/index.php/diglosia/article/view/26

\section{PENGEMBANGAN BAHAN AJAR MENULIS TEKS CERPEN DENGAN METODE CERPEN-GRAM UNTUK SISWA KELAS IX DI KECAMATAN MUARA WAHAU}

\section{Development of Short Story Writing Teaching Materials Using Cerpen-gram Method for Ninth Grade Students in Muara Wahau District}

\author{
Rajja $^{1, *}$, M. Bahri Arifin ${ }^{2}$, Mursalim ${ }^{3}$ \\ ${ }^{1}$ Magister Pendidikan Bahasa dan Sastra, FKIP Universitas Mulawarman \\ ${ }^{2,3}$ Universitas Mulawarman \\ Pos-el Korespondensi: rajjawahau@gmail.com
}

\begin{abstract}
The purpose of this research is to develop teaching materials for writing short stories using cerpen-gram method for grade 6 students in Muara sub-district, the scope of this development is limited to planning, materials, and evaluation in the process of developing teaching materials. The method used in this study is research and development (RED), using the Brog and Gall. The data source that became the object of this research was grade IX students of SMPN 2 Muara Wahau. Development planning is carried out by analyzing student needs, experiences faced by students, preparing learning traps in the form of syllabus, lesson plans, materials, evaluation tools and preparation of learning steps with the Gram-short story method. The development of teaching materials for writing short text texts was declared to be very feasible through material expert testing (95.83\%), method experts were declared very feasible (82.81\%), education practitioners were declared very feasible (87.5\%) with the same category that is very worthy. Small group trials $(88.2 \%)$, large groups $(87.13 \%)$, the results of student responses to small and large group trials $(86.93 \%)$, and planning assessments were declared very feasible (84.66) for $1^{\text {st }}$ observers, $2^{\text {nd }}$ observer (88.33) with a very decent category. implementation evaluation (89.22\%) by observer 1 and observer 2 (91.13\%) Development of teaching materials for writing short text using the short-Gram method to improve student learning outcomes with results (87.31\%). The teaching material product for writing short stories can be used as a source of support in the learning process and as an alternative source of independent learning by students so that they are more motivated to learn. Teaching products for writing short text can be disseminated to other schools in Muara Wahau district.
\end{abstract}

Keywords: teaching material, writing short story, cerpen-gram

\begin{abstract}
Abstrak: Tujuan penelitian ini untuk pengembangan bahan ajar menulis teks cerpen dengan metode cerpen gram untuk siswa SMPN kelas IX di Kecamatan Muara Wahau ruang lingkup pengembangan ini dibatasi hanya perencanaan, materi, dan evaluasi dalam proses pengembangan bahan ajar. Metode yang digunakan dalam penelitian ini adalah research and development (R\&D), dengan menggunakan desain penelitian pengembangan Brog dan Gall. Sumber data yang menjadi objek penelitian ini adalah siswa kelas IX SMPN 2 Muara Wahau. Perencanaan pengembangan bahan ajar dilakukan dengan menganalisis kebutuhan siswa, kendala yang dihadapi siswa, mempersiapkan perangkap pembelajaran berupa Silabus, RPP, materi, alat evaluasi dan penyusunan langkah-langkah pembelajaran dengan metode cerpen-gram. Pengembangan bahan ajar menulis teks cerpen ini dinyatakan sangat layak melalui uji ahli materi $(95,83 \%)$, ahli metode menyatakan sangat layak $(82,81 \%)$, praktisi pendidikan menyatakan sangat layak $(87,5 \%)$ dengan kategori yang sama yakni sangat layak. Uji coba kelompok kecil $(88,2 \%)$, kelompok besar $(88,13 \%)$, hasil respons siswa uji coba kelompok kecil dan besar $(86,93 \%)$, dan penilaian perencanaan dinyatakan sangat layak $(84,66)$ pengamat 1 , pengamat $2(88,33)$ dengan kategori sangat layak. penilaian pelaksanaan $(89,22 \%)$ oleh pengamat 1 dan pengamat 2 (91,13\%) Pengembangan bahan ajar menulis teks cerpen dengan metode cerpen-gram untuk meningkatkan hasil belajar siswa dengan hasil $(88,13 \%)$. Produk bahan ajar menulis teks cerpen ini dapat dijadikan sumber penunjang dalam proses pembelajaran dan sebagai sumber belajar alternatif
\end{abstract}


secara mandiri oleh peserta didik sehingga lebih termotivasi untuk belajar. Produk bahan ajar menulis teks cerpen dapat diseminasi pada sekolah-sekolah lain di Kecamatan Muara Wahau.

Kata kunci: bahan ajar, menulis cerpen, metode cerpen-gram

\section{A. PENDAHULUAN}

Mata pelajaran Bahasa Indonesia bertujuan agar para siswa memiliki kompetensi bahasa Indonesia untuk berbagai fungsi komunikasi dalam berbagai kegiatan sosial. Masroro (2015, hal. 4) Kegiatan yang dirancang dalam pembelajaran diharapkan dapat membantu siswa mengembangkan kompetensi berbahasa, kognisi, kepribadian, dan emosi siswa. Selain itu, pembelajaran Bahasa Indonesia diharapkan dapat mengembangkan minat baca dan minat menulis.

Sayangnya, kompetensi menulis teks cerpen belum dikuasai siswa dengan baik. Bagi siswa, menulis cerpen adalah pekerjaan yang berat. Sugiono (2013, hal. 171) menyatakan bahwa menulis karya sastra bagi siswa merupakan kegiatan yang sangat berat. Setelah menemukan ide, ia ketik kemudian dibaca, belum sampai setengah halaman, ia hapus lagi. Diketik lagi dan dihapus lagi. Mawenda (2015, hal. 121) mengungkapkan menulis cerpen bagi sebagian siswa dianggap sebagai pelajaran yang membosankan bahkan cenderung menjadi beban dalam belajar. Beberapa di antaranya mengakui tidak tahu apa yang harus ditulis dan untuk apa mereka menulis cerpen. Suyuti et al. (2015, hal. 121) menyatakan bahwa kendala pembinaan menulis karya sastra yang berasal dari pihak siswa tampak dalam hal motivasi, pengembangan ide, dan teknik penyajian.

Diskusi yang dilakukan dengan guru mata pelajaran bahasa Indonesia dalam MGMP Bahasa Indonesia Kabupaten Kutai Timur juga menunjukkan kondisi yang tidak berbeda. Maksud tidak berbeda adalah siswa masih sulit menulis cerpen dan tidak bisa mengembangkan tema cerita. Siswa memahami struktur teks cerpen. Namun, ketika mulai mengembangkan tema cerita, siswa menemui "kegalauan" seperti sudah menulis judul cerpen namun tiba-tiba tidak tahu kelanjutannya (mengalami kebuntuan dalam melanjutkan alur cerita) serta, sulitnya mengembangkan ide cerita. Selain itu, guru-guru juga mengeluhkan pengembangan materi menulis cerpen dalam buku siswa yang cenderung menekankan aspek struktur teks cerpen. Pembelajaran kurang melatih kemampuan menulis isi cerpen dengan kekhasan bahasanya. Akibatnya, cerpen dipahami sebagai teks yang dibangun atas bagian orientasi di bagian awal, komplikasi di bagian tengah, dan resolusi di bagian akhir. Pemahaman seperti ini akan menghilangkan makna bahwa cerpen itu ekspresif, imajinatif, dan estetis. Guruguru berharap buku siswa juga berisi pengalaman belajar mengembangkan unsur-unsur intrinsik cerpen. Siswa dilatih menggali ide cerita, mengembangkan karakter tokoh, dan menciptakan alur cerita yang menarik.

Berdasarkan kajian secara mendalam terhadap bahan ajar yang digunakan di sekolah-sekolah di Kabupaten Kutai Timur, KD menulis teks cerpen telah dikembangkan sesuai dengan standar kelayakan bahan ajar yang telah ditentukan oleh Kemendiknas. Walaupun demikian, ada dua temuan yang menurut yang sangat esensial. Pertama, bahan ajar belum memberikan materi yang dibutuhkan siswa karena terlalu singkat. Cakupan materi yang singkat tentu memberikan informasi yang tidak jelas kepada siswa perihal unsur pembangun cerpen misalnya. Akibatnya, keterampilan menulis cerpen siswa sulit ditingkatkan karena konstruksi pemahaman siswa perihal teks cerpen tidak memadai. Kedua, pembelajaran menulis teks cerpen dalam bahan ajar belum menyajikan langkah 
praktis menulis cerpen. Menulis cerpen merupakan proses kreatif. Proses yang penahapannya mendukung pembelajar untuk mengembangkan kreativitas imajinatif. Tanpa itu, sekat-sekat penyumbat imajinasi siswa tidak akan hilang sehingga kreativitas menulis cerpen siswa sulit berkembang.

Berdasarkan uraian tersebut, ada banyak kendala yang dihadapi siswa ketika menulis cerpen. Setidaknya, ada dua masalah utama dalam pembelajaran menulis cerpen. Pertama, siswa sulit mengembangkan ide atau tema cerita. Kedua, buku siswa kurang melatih keterampilan menulis cerpen. Di sisi lain, guru juga belum menggunakan teknik pembelajaran menulis cerpen yang tepat sehingga siswa masih sulit menulis cerpen. Dengan demikian, perlu solusi yang tepat untuk mengatasinya persoalan tersebut. Membuat pengembangan bahan ajar menulis kreatif cerpen sebagai solusi terbaik. Bahan ajar yang dikembangkan berupa buku pelajaran menulis kreatif teks cerpen. Pengorganisasian materi dalam buku menggunakan pendekatan berbasis teks sedangkan pembelajaran menulis cerpen dengan menggunakan metode cerpen-gram.

Pengorganisasian materi menulis cerpen dengan pendekatan berbasis teks membantu siswa menulis teks cerpen secara terbimbing. Pendekatan berbasis teks terdiri atas empat bagian: membangun konteks, permodelan, prakonstruksi, dan konstruksi. Pada bagian awal, siswa mengidentifikasi teks cerpen secara umum dari segi pengertian dan ciri-cirinya. Pada bagian permodelan, siswa dibekali dengan kompetensi pengetahuan dan pemahaman tentang bagaimana menyusun atau menciptakan teks melalui mencermati model teks. Pada bagian prakonstruksi, siswa dibimbing menulis teks cerpen secara berkelompok. Pada bagian terakhir, konstruksi, siswa menulis teks cerpen secara mandiri. Dengan pendekatan ini, siswa melakukan kegiatan pembelajaran menulis teks cerpen secara bertahap dan terbimbing.

Selain itu, pendekatan berbasis teks (genre-based approacb) merupakan salah satu fondasi pengembangan teoretis Kurikulum 2013. Pendekatan lainnya yaitu pendekatan ilmiah dan CLIL (content language integrated learning). Pendekatan berbasis teks merupakan konsep utama pengembangan buku teks kurikulum 2013. Oleh sebab itu, pemilihan mengembangkan bahan ajar menulis cerpen sangat tepat. Selanjutnya, pelatihan menulis cerpen menggunakan metode cerpen-gram. Metode cerpen-gram sangat efektif bagi calon penulis pemula cerpen. petunjuk praktis cerpen-gram tidak saja memberikan tips menulis secara praktis dan sederhana, tetapi juga motivasi untuk berlaku imajinatif, belajar tekun dan selektif, menggiring penulis pemula mampu mengeksplor sesuai langkahlangkah cerpen-gram. Oleh sebab itu, pemilihan metode cerpen-gram sangat tepat dijadikan solusi untuk mengatasi kesulitan siswa dalam mengembangkan ide cerita.

Metode cerpen-gram diperuntukkan bagi penulis pemula yang kesulitan dalam memulai menulis cerpen. Metode cerpengram dicetuskan oleh Peng Khen Sun. Metode cerpen-gram ini bertujuan memberikan alternatif dan teknik menulis cerpen bagi penulis pemula dengan langkah-langkah yang sederhana dan sistematis sehingga dengan langkahlangkah metode cerpen-gram memberikan kemudahan bagi penulis pemula untuk berpikir secara kritis dan imajinatif secara tertata.

Cerpen-gram adalah $\begin{array}{r}\text { metode } \\ \text { sederhana dan praktis }\end{array}$
memudahkan para penulis pemula
menulis cerpen (Sun, 2016, hal. xi). Salah
satu keunggulan metode cerpen-gram
adalah lebih mengandalkan praktik
menulis bagian-bagian cerpen seperti
pembuka, dialog, deskripsi, konflik, dan
penutup. Cerpen-gram memiliki berbagai


manfaat memudahkan proses menulis cerpen, memudahkan belajar menulis cerpen dari karya-karya yang sudah dipublikasikan, memudahkan belajar teori menulis cerpen sambil praktik, memudahkan mengenali pola penulisan bagian-bagian cerpen seperti pembuka, penutup, dialog, monolog, konflik, dan sebagainya, memudahkan menulis sinopsis cerpen, memudahkan berimajinasi untuk membangun cerita, memudahkan menulis ide untuk menulis cerpen, membuat menulis cerpen menjadi kegiatan yang mudah, menyenangkan, dan lebih bermanfaat (Sun, 2016, hal. xii).

Pengembangan bahan ajar yang lakukan berbeda dengan penelitianpenelitian tersebut. Ada dua perbedaan utama: (1) pengembangan bahan ajar berbasis teks dan (2) pelatihan keterampilan menulis cerpen menggunakan metode cerpen-gram. berkeyakinan bahwa bahan ajar yang dikembangkan memenuhi unsur relevansi dan kebaruan: relevan karena pendekatan berbasis teks merupakan konsep utama pengembangan buku teks kurikulum 2013 revisi dan baru karena materi pada buku pelajaran yang dikembangkan bersumber pada kurikulum 2013 revisi yang diberlakukan di awal tahun pelajaran 2016/2017. Dengan demikian, pengembangan bahan ajar yang dilakukan benar-benar diperlukan.

Pembelajaran adalah proses interaksi antara peserta didik dengan pendidik serta sumber belajar pada suatu lingkungan belajar. Pembelajaran merupakan bantuan yang diberikan pendidik agar dapat terjadi proses pemerolehan ilmu dan pengetahuan, penguasaan kemahiran dan tabiat, serta pembentukan sikap dan kepercayaan pada peserta didik. Dengan kata lain, pembelajaran adalah proses untuk membantu peserta didik agar dapat belajar dengan baik. Istilah pembelajaran sama dengan instruction atau pengajaran. Pengajaran mempunyai arti cara mengajar atau mengajarkan. Dengan demikian pengajaran diartikan sama dengan perbuatan belajar (oleh siswa) dan mengajar (oleh guru). Kegiatan belajar adalah kegiatan primer, sedangkan mengajar adalah kegiatan sekunder yang dimaksudkan agar terjadi kegiatan secara optimal. Pembelajaran secara simpel dapat diartikan sebagai produk interaksi berkelanjutan antara pengembangan dan pengalaman hidup. Dalam makna yang lebih kompleks, pembelajaran hakikatnya adalah usaha sadar dari seorang guru untuk memberikan pelajaran siswanya (mengarahkan interaksi siswa dengan sumber belajar lainnya) dalam rangka mencapai tujuan yang diharapkan.

Menulis adalah: (1) membuat huruf (angka dsb.) dengan pena, (2) melahirkan pikiran atau perasaan (seperti mengarang, membuat surat) dengan tulisan, (3) menggambar, melukis, (4) membatik kain. Kamus Besar Bahasa Indonesia (KBBI) (2005, hal. 1219). Pengertian yang lain menulis adalah aktivitas memindahkan pengalaman dalam simbol-simbol. Wamene (2015, hal. 9). Selain itu menulis adalah suatu proses kreatif memindahkan gagasan ke dalam lambang-lambang tulisan. Sufanti (2013, hal. 14). Pendapat lain mengungkapkan menulis adalah penuangan pikiran terbaik dalam proses berpikir di atas kertas mengenai suatu gagasan (Endraswara, 2003, hal. 237). Dalam menulis terdapat hubungan keterampilan berbahasa yang bersifat produktif, artinya keterampilan menulis ini merupakan keterampilan yang menghasilkan; dalam hal ini menghasilkan tulisan. Keterampilan menulis seseorang bukan dibawa sejak lahir, melainkan diperoleh melalui tindak pembelajaran. Akan tetapi, seseorang yang telah mendapat pembelajaran menulis belum tentu memiliki kompetensi menulis dengan andal tanpa banyak latihan menulis (Pranoto, 2011, hal. 94). Dengan demikian, keterampilan menulis tidak diperoleh secara otomatis. Tujuan menulis yaitu untuk menceritakan sesuatu, untuk 
memberikan petunjuk atau pengarahan, untuk menjelaskan sesuatu, untuk meyakinkan, dan untuk merangkum. Nurgiantoro (2013, hal. 14). Selain itu tujuan menulis adalah menginformasikan, membujuk, mendidik, dan menghibur. Dapat disimpulkan bahwa menulis merupakan kegiatan menuangkan ide, pikiran, gagasan, dan pengalaman ke dalam tulisan sebagai upaya penyampaian pesan kepada pembaca.

\section{B. METODE}

Penelitian ini menggunakan model penelitian dengan istilah Research \& Development (R\&D). Metode penelitian dan pengembangan adalah metode yang digunakan untuk menghasilkan produk tertentu, dan menguji keefektifan produk tersebut. Sugiyono (2016, hal. 407). Penelitian pengembangan bahan ajar menulis teks cerpen dengan metode Cerpen-gram adalah penelitian menggunakan metode pengembangan Research and Development yang diadaptasi oleh Sugiyono.

Penelitian ini dilakukan secara bertahap, yakni dari perencanaan dan perancangan penelitian, menentukan fokus penelitian, waktu penelitian, pengumpulan data, analisis, dan penyajian hasil penelitian. Pendekatan dalam penelitian ini mengikuti langkah-langkah kerja penelitian kualitatif dan kuantitatif. Dalam hal ini di sebut kualitatif karena data kualitatif diperoleh dari kritik, saran, komentar para ahli terhadap media pembelajaran. Uji coba lapangan data kualitatif berupa hasil observasi dan wawancara. Sedangkan kuantitatif diperoleh dari angket atau kuesioner yang diberikan kepada validator untuk menilai produk pengembangan.

Teknik analisis data dalam penelitian ini adalah pada langkah awal ini peneliti akan melakukan tahap I studi pendahuluan yang terdiri dari observasi dan wawancara kepada guru dan siswa untuk mengetahui kondisi dan kebutuhan pada pembelajaran menulis cerpen. Instrumen yang diperlukan adalah berupa teks wawancara dan angket analisis kebutuhan yang terkait pembelajaran menulis cerpen. Selanjutnya dilakukan Tahap II yaitu tahap pelaksanaan pengembangan bahan ajar yang terdiri dari mendesain materi yang dikembangkan, data yang diperlukan adalah desain materi dan desain pengembangan bahan ajar menulis cerpen. Tahap III akan dilakukan uji coba produk yang terdiri dari validasi desain dari para ahli untuk menguji kelayakan produk dengan menggunakan lembar validasi, revisi desain, uji coba produk yang terdiri dari tulisan/karangan siswa dan hasil belajarnya.

Semua data yang diperoleh lalu diolah untuk mewujudkan pengembangan bahan ajar pembelajaran yang layak dan efektif digunakan dalam pembelajaran menulis cerpen. Teknik analisis data yang digunakan secara kuantitatif untuk data tes dan secara kualitatif untuk data nontes. Alat pengumpulan data berupa pedoman observasi, pedoman wawancara, dan pedoman penulisan cerpen. Pengumpulan data menggunakan teknik simak dan catat.

\section{PEMBAHASAN}

Hasil penelitian berupa data kuantitatif dan data kualitatif yang disajikan secara formal dan informal. Data kuantitatif yang disajikan secara formal mencakup angka-angka dan persentase dari perhitungan nilai prestasi dan nilai respons siswa pada kuesioner. Peningkatan prestasi siswa secara keseluruhan dapat dinilai berdasarkan perolehan nilai. Gambar dan tabel membantu untuk menyajikan data formal dalam penelitian ini. Dengan menggunakan rumus yang dijelaskan melalui uraian-uraian secara deskriptif terdapat perhitungan peningkatan nilai dan respons siswa baik sebelum dan sesudah melakukan penelitian. Sementara itu, data kualitatif yang disajikan secara informal dalam bentuk uraian. Selanjutnya 
hasil berupa peningkatan kemampuan menulis cerpen dengan metode cerpengram dikaji melalui beberapa teori menulis cerpen berdasarkan kriteria penilaian cerpen, yakni kesesuaian judul dengan tema, kesesuaian alur dan rangkaian cerita, kesesuaian pelaku, kesesuaian latar, penulisan ejaan. Penjabaran ini merupakan bagian inti dari analisis yang berfungsi melengkapi penyajian data-data formal sebelumnya, terutama yang terkait dengan peningkatan kemampuan menulis cerpen siswa.

Tahap studi pendahuluan dilaksanakan untuk menganalisis informasi awal mengenai kondisi di SMP Negeri 2 Muara Wahau. Penelitian ini diawali dengan melakukan observasi. Berdasarkan observasi langsung di SMP Negeri 2 Muara Wahau dan hasil diskusi dengan guru mata pelajaran Bahasa Indonesia, peneliti memperoleh informasi, di antaranya: (1) dalam pembelajaran menulis cerpen siswa kelas X SMP Negeri 2Muara Wahau masih kurang berminat dan pasif; (2) dalam pembelajaran menulis, diperlukan perencanaan materi dan penilaian yang sesuai dengan tingkat kemampuan siswa, (3) ppenggunaan metode sangat diperlukan sebagai penunjang pembelajaran menulis cerpen.

Pada tahap desain dihasilkan produk perencanaan pengembangan pembelajaran menulis cerpen berupa rencana pelaksanaan dan perencanaan evaluasi pembelajaran sebagai pedoman selama pelaksanaan pembelajaran di SMP Negeri 2 Muara Wahau. Penyusunan materi dalam buku tersebut mengacu pada materi teknik pembelajaran cerpen. Indikator pelaksanaan pembelajaran menulis cerpen mengacu pada kurikulum 2013 sekolah Tingkat SMP.

Dalam penelitian ini, silabus dan rencana pelaksanaan pembelajaran (RPP) disusun untuk memperoleh data dalam persiapan yang dilakukan guru dan rencana dalam kegiatan pembelajaran. Materi pertama sebagai pendahuluan yang merupakan awal pembelajaran menulis cerpen yaitu dengan memperkenalkan materi unsur-unsur pembangun dalam cerpen. Materi berikutnya adalah menayangkan beberapa video yang disesuaikan dengan tema cerpen.

Tahap pengembangan adalah mengembangkan perencanaan pembelajaran berdasarkan kegiatan sebelumnya. Proses Kegiatan pada tahap ini adalah sebagai berikut. Pertama, tahap validasi desain yang merupakan proses rangkaian validasi dilaksanakan oleh validasi ahli materi, validasi ahli metode, dan validasi praktisi pendidikan. Dengan validator yang berkompeten dan mengerti pada bidangnya masing-masing. Validator diharapkan mampu memberi masukan/saran untuk menyempurnakan pengembangan bahan ajar menulis cerpen. Kedua, tahap revisi desain berdasarkan saran-saran yang diberikan oleh validator pada saat validasi untuk menghasilkan produk pengembangan yang layak. Validasi materi dilakukan hanya satu kali karena hasil validasi sudah sangat layak dengan jumlah skor $91,66 \%$. Validasi materi dilakukan hanya sekali karena hasil pengembangannya sudah sangat layak. Pada validasi metode dilakukan dua kali Pertemuan pertama validator memberikan saran dan arahan untuk perbaikan bahan ajar. Pada pertemuan kedua setelah direvisi, Validator memberikan penilaian $82,81 \%$.

Hasil validasi diinterpretasikan dengan skala $86 \%-100 \%$ sehingga dikategorikan sangat layak dengan keputusan produk siap dipakai di lapangan tanpa revisi. Hasil rekapitulasi dengan kategori tersebut menunjukkan bahwa pengembangan bahan ajar menulis teks cerpen dengan metode cerpen-gram memiliki kualitas yang sangat layak digunakan siswa sebagai penunjang kegiatan pembelajaran.

Proses uji coba kelompok kecil dilaksanakan di SMP Negeri 2 Muara Wahau pada 15 Juli 2019. Waktu 
pelaksanaan pukul 7.30-09.00 Wita, materi yang disampaikan adalah menulis cerpen berdasarkan unsur-unsur pembangunnya. Jumlah siswa uji coba adalah 10 orang siswa dan 2 orang pengamat. Tujuan uji coba ini adalah mengetahui keterlaksanaan rencana pelaksanaan pembelajaran, respons guru dan siswa, dan aktivitas guru dan siswa terhadap desain perencanaan pembelajaran. Berdasarkan hasil uji coba kelompok kecil diperoleh nilai 88,2. Sedangkan uji coba kelompok besar atau uji lapangan dengan nilai yang diperoleh 88,13 . Respons kelompok kecil mencapai nilai 88,19 dan respons uji lapangan nilai yang diperoleh 89,35. Respons guru berdasarkan jawaban dari uji kelompok kecil dan uji kelompok besar disimpulkan bahwa bahan ajar menulis cerpen memenuhi syarat sebagai bahan ajar pembelajaran.

Dari keseluruhan data yang diperoleh membuktikan bahwa hasil uji coba ini terdiri atas hasil akhir dari ketiga validator dikategorikan sangat layak. Hasil uji kelompok kecil dan hasil uji kelompok besar terhadap pengembangan bahan ajar menghasilkan nilai rata-rata yang sangat signifikan terhadap bahan ajar menulis cerpen. Demikian juga dengan respons siswa uji kelompok kecil dan respons uji kelompok besar serta hasil wawancara guru yang memberikan penilaian yang sangat layak. Perencanaan pembelajaran oleh pengamat 1 dengan rata-rata nilai $84,37 \%$, pengamat 2 rata-rata nilai $89,06 \%$. Dan pelaksanaan pembelajaran oleh pengamat 1 dan 2 rata-rata nilai sama yaitu $89,65 \%$ dan memperoleh kategori sangat layak. Adapun hasil belajar siswa dengan pengembangan bahan ajar menulis nilai rata-rata adalah 87,13.

setelah dilakukan pengembangan bahan ajar dengan menggunakan metode cerpen-gram yang telah dikembangkan melalui tahapan proses dari validasi awal dan validasi akhir hingga menjadi bahan ajar yang sangat layak diujicobakan kepada siswa, telah diperoleh hasil belajar siswa sebesar 88,13\% yang berarti mencapai batas KKM, yaitu 75. Ini menggambarkan bahwa kriteria efektivitas pertama telah tercapai dan pengembangan bahan ajar pada materi menulis cerpen efektif digunakan. Setelah uji coba awal rata-rata sebesar $68,47 \%$ sedangkan pada uji coba akhir dengan nilai rata-rata sebesar 88,13\%. Dengan membandingkan data nilai uji awal dan nilai uji coba akhir bahwa terjadi peningkatan nilai. penilaian perencanaan oleh pengamat 1 dengan nilai $84,66 \%$ dan pengamat 2 dengan nilai $89,00 \%$. penilaian pelaksanaan pembelajaran oleh pengamat 1 dengan nilai $89,22 \%$ dan pengamat 2 dengan nilai $91,13 \%$. Hal ini menunjukkan bahwa keterlaksanaan perencanaan dan pelaksanaan pembelajaran telah diperoleh hasil yang sangat layak.

\section{PENUTUP}

Secara umum dapat disimpulkan bahwa pengembangan bahan ajar menulis cerpen mampu membawa siswa dalam mencapai kriteria ketuntasan minimal (KKM) yang berlaku yakni 75. Hasil belajar telah menunjukkan bahwa pengembangan bahan ajar mampu meningkatkan hasil belajar siswa yang dapat dilihat dari nilai capaian sebelum menggunakan pengembangan dan sesudah menggunakan pengembangan. Efektivitas juga ditandai oleh keberhasilan dalam pelaksanaan pengembangan bahan ajar menulis teks cerpen dengan menggunakan pengembangan bahan ajar sesuai dengan perencanaan yang telah dirancang sebelumnya.

Penelitian pengembangan bahan ajar ini berupaya memfasilitasi dan meningkatkan kemampuan guru dalam mengembangkan bahan ajar sesuai dengan kebutuhan peserta didik melalui tahapantahapan penelitian pengembangan sebagai suatu penelitian yang sistematis pada proses desain, pengembangan dan evaluasi dengan tujuan membangun dasar empiris untuk penciptaan produk-produk 
pembelajaran yang seharusnya menjadi prioritas utama bagi peneliti dalam bidang studi bahasa Indonesia.

Produk pengembangan bahan ajar yang baik harus memenuhi kriteria validitas, praktikalitas dan efektivitas di mana penelitian pengembangan ini bertujuan untuk meningkatkan kemampuan peserta didik dalam memahami pelajaran khususnya menulis teks cerpen yang dirancang sesuai dengan kompetensi guru, sarana prasarana yang ada serta fasilitas pendukung lainnya. Pengembangan suatu produk harus didasarkan pada hasil analisis kebutuhan peserta didik sehingga produk yang akan dikembangkan benar-benar relevan dengan tujuan pembelajaran yang ditetapkan atau bahan ajar pembelajaran untuk mendorong peserta didik agar dapat belajar mandiri.

\section{DAFTAR PUSTAKA}

Aksan, H. (2015). Proses Kreatif Menulis Cerpen. Bandung: Nuansa Cendekia.

Alwi, H., et al. (2003). Tata Bahasa Baku Bahasa Indonesia. Edisi Ketiga. Jakarta: Balai Pustaka.

Amalia, A. \& Doyin, M. (2016). Pengembangan Buku Panduan Menyusun Teks Cerpen dengan Menggunakan Teknik Urai Unsur Intrinsik Bagi Siswa Kelas VII Sekolah Menengah Pertama (SMP). Jurnal Pendidikan Bahasa dan Sastra Indonesia, 5(1).

Depdiknas. (2008). Panduan Pengembangan Bahan Ajar. Jakarta: Dirjen Dikdasmen.

Endraswara, S. (2003). Membaca, Menulis, dan Mengajarkan Sastra. Yogyakarta: Kota Kembang.

Ghazali, A. (2009). Strategi Belajar Kooperatif dalam Belajar Mengajar Kontektual. Jurnal Pendidikan dan Pembelajaran (JPP), 9(1).

Harsiati, T., et al. (2016). Buku Guru Bahasa Indonesia SMP/MTs Kelas VII. Jakarta: Kemendikbud.
Hidayati, K. (2010). Menulis Kreatif Cerpen. Diperoleh dari http://kartikahidayati.blogspot.co.id /2010/12/menuliskreatifcerpen.html

Himang, V. H. (2019). Pengembangan Bahan Ajar Menulis Cerpen Berbasis Pengalaman Siswa Kelas XI SMK. Diglosia: Jurnal Kajian Bahasa, Sastra, Dan Pengajarannya, 2(2), 93-102. http://diglosiaunmul.com/index.ph $\mathrm{p} /$ diglosia/article/view/21

Kemendikbud. (2015). 15 Naskah Terbaik Lomba Menulis Cerita Remaja (LMRC) 2014. Jakarta: Kemendikbud.

Kemendikbud. (2015). Pedoman Umum Ejaan Bahasa Indonesia. Jakarta: Depdikbud.

Khulsum, U., Hudiyono, Y., \& Sulistyowati, E. D. (2019). Pengembangan Bahan Ajar Menulis Cerpen dengan Media Storyboard pada Siswa Kelas X SMA. Diglosia: Jurnal Kajian Bahasa, Sastra, Dan Pengajarannya, 1(1), 1-12. http://diglosiaunmul.com/index.ph $\mathrm{p} /$ diglosia/article/view/4

Lestari. (2015). Pengembangan Bahan Ajar Menulis Cerpen Berbasis Proyek dengan Pendekatan Kontekstual untuk Meningkatkan Kemampuan Siswa Menulis Cerpen. Metafora, 2(1).

Masroroh, A. (2015). Pengembangan Modul Pembelajaran Menulis Cerpen Berbasis Pengalaman (Experiential Learning) Untuk Siswa SMP/MTs. Diperoleh dari https://eprints.uny.ac.id/27649/

Mawene, A. (2015). Lagu dan Cerpengram. Jawa Timur: Surya Pena Gemilang.

Nurgiyantoro, B. (2013). Teori Pengkajian Fiksi. Yogyakarta: Gadjah Mada University Press.

Nurhadi, et al. (2007). Bahasa Indonesia untuk SMP Kelas IX. Jakarta: Erlangga.

Pranoto, N. (2011). Creative Writing Telaga Inspirasi Menulis Fiksi. Bogor: Rayakultura. 
Sufanti, M. (2013). Pembelajaran Bahasa Indonesia Berbasis Teks: Belajar dari Obio Amerika Serikat. Diperoleh dari http://hdl.handle.net/11617/3363

Sugiono, et al. (2013). Kamus Besar Bahasa Indonesia. Jakarta: Gramedia Pustaka Utama.

Sugiyono. (2016). Metode Research and Development. Jakarta: Pustaka Media.

Sun, P. K. (2016). Menggali Passion Menulis Cerpen dengan Cerpen-gram. Jakarta: Gramedia.
Suyuti, et al. (2015). Kamus Bahasa Indonesia Baru. Bandung: Nala Cipta.

Trianto, A. (2014). Buku Siswa Bahasa Indonesia SMP/MTs Kelas IX. Jakarta: Kemendikbud.

Tysna, A. W. I. (2014). Ragam bahasa. Diperoleh

dari https://www.academia.edu/9534983 /makalah_bahasa_indonesia_ragam_ bahasa

Zabadi, F., et al. (2014). Babasa Indonesia Wabana Pengetabuan SMP/MTs Kelas VII. Jakarta: Kemendikbud RI. 